\title{
DIETARY IMPROVEMENT OF THE IRON STATUTE OF THE RATS WITH EXPERIMENTAL ANEMIA
}

\author{
Rodica STURZA ${ }^{1}$, Valentin GUDUMAC ${ }^{2}$, Olga DESEATNICOVA ${ }^{1}$, Aliona GHENDOV-MOSANU ${ }^{1}$ \\ 1Faculty of Food Technology, Technical University of Moldova, Chisinau, Republic of Moldova \\ ${ }^{2}$ Nicolae Testemiteanu State University of Medicine and Pharmacy of the Republic of Moldova, Chisinau, Republic \\ of Moldova
}

Corresponding author: Aliona Ghendov-Moșanu, e-mail: aliona.mosanu@tpa.utm.md

DOI: $10.38045 /$ ohrm.2021.1.02

UDC: $616.155 .194 .8-092.9+613.2$

Key words: iron anemia, rats, in vivo research, fortified bread, lactic acid fermentation, peripheral blood parameters, serum iron.

Cuvinte cheie: anemie feriprivă, șobolani, cercetări in vivo, pâine fortificată, fermentatie acido-lactică, parametri ai sângelui periferic, fier seric.
Introduction. One of the major problems characterizing the nutritional status is the iron deficiency, which leads to decreased immunity, increased incidence of infectious diseases and anemia. Obviously, only well-thought-out corrections can solve these disorders.

Material and methods. In order to know the influence of the method of manufacture for iron-fortified products on the iron level, a series of in vivo research was carried out, on a batch of 21 white rats, Wistar line, which were induced experimental drug anemia (EDA). The blood analysis was performed in three stages: initially, after the induction of EDA and after the completion of the experiment.

Results. Investigations showed out that during sufficient iron intake rehabilitation of the body iron reserve depends considerably on the presence of antinutritive factors. In order to decrease the influence of these factors, the production method used for fortified products with mineral origin micronutrients (iron) could be based on the use of the lactic-acid fermentation procedures using wheat bran.

Conclusions. The research carried out on laboratory animals with induced experimental anemia showed that, in the case of the group fed with bread manufactured by the acidlactic fermentation method, the concentration of serum, iron was completely restored during the experiment, and in the rats fed with fortified bread prepared by the traditional method, the serum iron concentration was only partially restored, 40-45\%.

\section{AMELIORAREA DIETARĂ A STATUTULUI DE FIER LA ȘOBOLANI CU ANEMIE EXPERIMENTALĂ}

Introducere. Una dintre problemele majore care afectează statutul nutrițional este insuficiența de fier, care duce la scăderea imunității, la sporirea incidenței maladiilor infecţioase şi a anemiilor. Și, evident, numai corecțiile echilibrate pot remedia aceste dereglări.

Material si metode. În scopul de a elucida influenţa metodei de fabricare a produselor fortificate cu fier asupra aportului acestuia în organism, au fost efectuate o serie de cercetări in vivo, pe un lot de 21 şobolani albi, linia Wistar, cărora li s-a indus anemie experimentală pe cale medicamentoasă (AEM). Analiza sângelui a fost efectuată în trei reprize: iniţial, după inducerea AEM şi, apoi după finalizarea experimentului.

Rezultate. Investigațiile au arătat, că chiar și la un aport suficient de fier, reabilitarea rezervei de fier a organismului depinde considerabil de prezența factorilor antinutritivi. Pentru a reduce influența acestor factori, metoda de fabricație aplicată, pentru produsele fortificate cu micronutrienți de origine minerală (fier), s-ar putea baza pe utilizarea procedurilor de fermentare acido-lactică, folosind tărâțe de grâu.

Concluzii. Cercetările efectuate pe animale de laborator, cu anemie experimentală indusă, au demonstrat, că în cazul grupei hranite cu pâine fabricată prin metoda cu fermentație acido-lactică, concentraţia fierului seric s-a restabilit complet pe durata experimentului, iar la şobolanii alimentați cu pâine fortificată, preparată prin metoda tradiţională, concentraţia fierului seric s-a restabilit doar parţial, în proporţie de 40-45\%. 
ABBREVIATIONS: $\boldsymbol{A} \boldsymbol{A}$, after anemia was induced; ASD, after special diet administration; $\boldsymbol{B} \boldsymbol{A}$, before anemia was induced; $\boldsymbol{e A L A S}$, erythroid-specific delta-aminolevulinic acid synthase; IFB, iron-fortified bread; $\boldsymbol{H B}$, hemoglobin concentration; $\boldsymbol{H T}$, hematocrit; IRE, iron-responsive element; IRE$\boldsymbol{B P}$, iron-responsive element-binding protein; LYM\%, percent report between lymphocyte and the total lymphocytes number; $\boldsymbol{L Y M}$, the absolute number of lymphocytes; $\boldsymbol{M C}$, myelocytes; $\boldsymbol{M C H C}$, average body concentration of the hemoglobin; $\boldsymbol{M C V}$, the average volume of erythrocyte; $\boldsymbol{M M C}$, metamyelocytes; $\boldsymbol{M P V}$, the average value of the platelet; $\boldsymbol{m R N A}$, messenger ribonucleic acid; $\boldsymbol{P A}$, phytic acid; $\boldsymbol{P D} \boldsymbol{W}$, platelet distribution amplitude; $\boldsymbol{P H Z}$, phenylhydrazine; $\boldsymbol{P}-\boldsymbol{L} \boldsymbol{C P}$, report between big platelet and the total platelet values; $P$ LT, platelet number; $\boldsymbol{R} \boldsymbol{B C}$, erythrocyte number; $\boldsymbol{R D} \boldsymbol{W}$, distribution amplitude of the erythrocytes; $\boldsymbol{S I}$, serum iron; UNICEF, United Nations International Children's Emergency Fund; $\boldsymbol{W B C}$, leukocyte number.

\section{INTRODUCTION}

Reduction of anemia is an important constituent of human health and a global nutrition target for 2025 (1). In low-income countries, the presence of anemia remains high and is a priority area (2). Up to half of the children and childbearing age women in developing countries and about $10 \%$ in developed countries are estimated to be iron deficient. Iron deficiency leads to impaired physical work performance, cognitive impairment, and adverse pregnancy outcomes. More and more evidences show that iron deficiency anemia in infants and toddlers can lead to irreversible development delays (3).

The study of the food consumption and nutritional status of Moldovan people, made with the support of UNICEF showed that the products used in women nutrition aged 18-45 years old contained only $28-53 \%$ of the iron daily amount (4). The consequence of this deficiency is the prevalence of iron deficiency anemia in $29 \%$ of the children aged 6-59 months (blood hemoglobin concentration $<110 \mathrm{~g} / \mathrm{L}$ ) and in $26 \%$ of non-pregnant women of reproductive age (15-49 years) (1). The level of significance of anaemia for public health is considered to be moderate.

Three intervention strategies are available to prevent iron deficiency and, therefore, iron deficiency anemia (5). These are supplements, dietary diversification, and both targeted and untargeted food fortifications. Food fortification programs are cost effective methods of reducing the prevalence of iron deficiency (6). The effectiveness of a food fortification program depends on the consistent and uniform addition of iron compounds to appropriate foods, such as flour, which are widely consumed by the target population (7, 8). Mineral intake and bioavailability are critical factors for meeting mineral nutritional needs $(9$, $10)$. Whole grain bread contains high levels of potassium, magnesium, iron, and zinc, but the presence of phytic acid compromises mineral and trace element absorption in humans (11). During bread making the content of phytic acid decreases due to the action of phytases in the dough (12). Nevertheless, if very little phytate is hydrolyzed in unleavened whole meal breads including breads containing sodium bicarbonate, phytic acid hydrolysis occurs during all stages of yeast bread making. Reduction of phytic acid content in different bread types varies between 13\% and $100 \%$, with the lowest decrease being in unleavened breads. The substantial decrease of phytic acid in whole wheat products can improve mineral availability in humans. Because consumption of whole grain breads is increasing, a whole wheat bread with low phytic acid levels and increased mineral bioavailability would be beneficial and attractive in improving mineral status and, hence, preventive nutrition.

A certain number of investigations showed that lactic-acid bacteria is capable to degrade phytic acid, and the lactic-acid fermentation increases calcium, magnesium, and iron solubility during in vitro investigations (13). Taken together, phytic acid degradation and lactic acid forming improved minerals bioavailability in the bread prepared through the lactic-acid method.

Most of the recent technological innovations, which decrease the duration of the transformation period of the agricultural material, can lead to a decrease of biological value of the foodstuffs and of its quality (14). But traditional diets of each region include different transformation procedures of the primary agricultural material, which are characteristic for the particular region and lead to the production of foodstuff that have physico-chemical and flavor characteristics, accepted by the majority of consumers. There is only one possibility to reduce the impact of the antinutritional factors on the foodstuff processing - development of technologies based on traditional procedures, verified over centuries, which 
allows to valorize the reserves of each particular region $(15,16,17)$. As bread represents the most essential foodstuff in the human nutrition, it is obvious that the main tendency is led towards development of such bread making procedures that would ensure a maximum biological value of the product $(18,19)$.

It was previously established that no-heme iron from the bread prepared through the lactic-acid method shows a higher bioavailability in vitro than the bread prepared through the traditional method (20). Simultaneously, a decrease of the phytic acid during in vitro gastro-intestinal digestion was identified. This shows that there is a direct relationship between potential bioavailability of iron in bread products and the hydrolysis degree of the phytates. In vivo studies, performed on rats showed that peripheral blood parameters of the laboratory animals are significantly improved compared to the control group, these were fed with fortified bread. But investigations did not allow to establish the influence of bread making procedure on the iron bioavailability because collected blood from both rat groups that were fed with a special diet (bread prepared through the traditional and lactic-acid fermentation method) do not show any distinctive differrences.

In order to investigate the influence of bread making procedure used for production of iron fortified products on the body iron status a range of in vivo investigations were drown on laboratory animals in which anemia was experimentally induced.

\section{MATERIAL AND METHODS}

\section{Materials}

For the investigations white wheat flour bread of high quality of autochthon production was used (21). As additive iron sulfate (II) was used $\left(\mathrm{FeSO}_{4} \cdot 7 \mathrm{H}_{2} \mathrm{O}\right)$ accepted as food additive by "Codex Alimentarius".

\section{Bread making procedures}

Bread was prepared by indirect (bi-phase) method, additive being added at the final knitting stage and through lactic-acid method. In order to reproduce the production of bread from integral wheat flour, reconstituted integral flour was used (flour with bran). For the production of bread with yeast $6 \mathrm{~kg}$ integral wheat flour $(4.65 \mathrm{~kg}$ wheat flour plus $1.35 \mathrm{~kg}$ bran) was mixed with 3.6 $\mathrm{L}$ distilled water and $150 \mathrm{~g}$ yeast (Saccharomyces cerevisiae). For lactic-acid fermentation the dough was prepared through the mixing of $1.2 \mathrm{~kg}$ integral wheat flour $(0.93 \mathrm{~kg}$ wheat flour and 0.27 $\mathrm{kg}$ bran) with $600 \mathrm{~mL}$ distilled water. After one day of natural fermentation at $30^{\circ} \mathrm{C}$, the dough was mixed with $4.8 \mathrm{~kg}$, integral wheat flour and 3 $\mathrm{L}$ distilled water. Bread was baked, dried, milled and introduced in the diet of rats.

\section{In vivo procedures}

Experiments were performed on a group of 21 white rats Wistar strain with the body weight 160-180 g which divided into 3 groups (7 rats each) in which experimental anemia was induced. Experimental anemia was reproduced for the laboratory female rats through repeated intramuscular injection of a $2 \%$ solution of phenylhydrazine (PHZ) prepared on physiological solution for 2 weeks (6 injections). Afterwards, the animals were kept on a special diet for 21 days, which included nutritional supplement bread, prepared via various methods and containing certain iron amount.

The first control group (Ia) represented animals, to whom were administered bread prepared via the classical biphase method without iron as nutritional supplement. The second group (IIa) included animals, which were fed with bread prepared by traditional bi-phase method with an addition of $8 \mathrm{mg}$ iron/100 g reconstituted flour. The third group (IIIa) included animals, which were fed with bread prepared by lactic-acid fermentation method with addition of $8 \mathrm{mg}$ iron/100 $\mathrm{g}$ reconstituted flour.

\section{Analyses of blood samples}

Biological material - peripheral blood collected from the laboratory animals was sampled before PHZ-induced anemia (BA), after PHZ-induced anemia (AA) and after special dietary administration (ASD) (22). Blood was collected in $1.5 \mathrm{~mL}$ Eppendorf test tubes. Blood indexes were determined in the peripheral heparinized blood in the hematology analyzer PCE-210 (ERMA, Japan). The following parameters were determined: red blood cell count (RBC), hemoglobin concentration (HGB), hematocrit value (HCT), mean corpuscular volume (MCV), mean corpuscular hemoglobin concentration (MCHC), red cell distribution width (RDW), platelets (PLT), mean platelet volume (MPV), platelet distribution width (PDW), platelet larger cell ratio (P-LCR), white blood cell count (WBC), absolute number of lymphocytes (LYM) and percentage of lymphocytes (LYM \%), mono- 
cytes (MONO), granulocytes (GRAN), unsegmented and segmented neutrophils, eosinophils, normocyte, serum iron (SI).

Blood serum was obtained through centrifugation of the peripheral blood at $2500 \pm 500 \mathrm{~min}^{-1}$ for 15 minutes. After centrifugation, blood serum was transferred in clean Eppendorf test tubes for single use and kept in the refrigerator at $4 \pm 1^{\circ} \mathrm{C}$ till the end of the experiments. The determination of the serum iron was performed by cromazurole test (Elitech, France) according to the annexed analyze instructions.

The research was approved by the Research Ethic Board of the Nicolae Testemiteanu State University of Medicine and Pharmacy of the Republic of Moldova, (favorable opinion of June 19, 2011).

\section{Statistics}

The analysis of the results variety was carried out by least square method with application of Student coefficient and Microsoft Office Excel program version 2007 (Microsoft Excel $\AA$ 2007, Microsoft Corp., Redmond, WA). The differences were considered statistically significant if probability was greater than 95\% ( $p$-value $<0,05$ ). All assays were performed at room temperature $20 \pm 1^{\circ} \mathrm{C}$. The experimental results are expressed as average $\pm \mathrm{SD}$ (standard deviation).

\section{RESULTS}

Blood parameters analysis collected from the animals with PHZ-induced anemia are presented in table 1.

Leukocyte formula for the laboratory animals before PHZ-induced anemia (BA), after PHZ-induced anemia (AA) and after special dietary administration (ASD) is presented in table 2 .

Table 1. Blood parameters analysis collected from animals before the PHZ-induced anemia (BA), after PHZ-induced anemia (AA) and after special dietary administration (ASD).

\begin{tabular}{lccccccccc}
\hline \multirow{2}{*}{$\begin{array}{l}\text { Blood } \\
\text { parameters }\end{array}$} & \multicolumn{3}{c}{ Ia } & \multicolumn{1}{c}{ IIa } & \multicolumn{3}{c}{ IIIa } \\
\cline { 2 - 11 } & BA & AA & ASD & BA & AA & ASD & BA & AA & ASD \\
\hline \multirow{2}{*}{ RBC (1012/L) } & $6.47 \pm$ & $2.16 \pm$ & $6.55 \pm$ & $6.31 \pm$ & $2.96 \pm$ & $6.65 \pm$ & $6.10 \pm$ & $2.64 \pm$ & $6.72 \pm$ \\
& 0.05 & 0.05 & 0.05 & 0.05 & 0.05 & 0.05 & 0.05 & 0.05 & 0.05 \\
\hline HGB (g/L) & $136 \pm 1$ & $59 \pm 1$ & $131 \pm 1$ & $139 \pm 1$ & $82 \pm 1$ & $147 \pm 1$ & $133 \pm 1$ & $73 \pm 1$ & $142 \pm 1$ \\
\hline \multirow{2}{*}{ HCT (L/L) } & $0.409 \pm$ & $0.229 \pm$ & $0.395 \pm$ & $0.400 \pm$ & $0.299 \pm$ & $0.41 \pm$ & $0.391 \pm$ & $0.279 \pm$ & $0.401 \pm$ \\
& 0.02 & 0.02 & 0.02 & 0.02 & 0.02 & 0.02 & 0.02 & 0.02 & 0.02 \\
\hline \multirow{2}{*}{ MCV (fL) } & $63.6 \pm$ & $113.9 \pm$ & $60.4 \pm$ & $63.1 \pm$ & $101.7 \pm$ & $63.3 \pm$ & $64.4 \pm$ & $106.5 \pm$ & $62.7 \pm$ \\
& 0.1 & 0.3 & 0.2 & 0.1 & 0.3 & 0.2 & 0.1 & 0.3 & 0.2 \\
\hline \multirow{2}{*}{ MCHC (g/L) } & $334.5 \pm$ & $275 \pm$ & $330.5 \pm$ & $350.0 \pm$ & $278 \pm$ & $361.5 \pm$ & $339.0 \pm$ & $261 \pm$ & $354.0 \pm$ \\
& 0.5 & 1 & 0.6 & 0.5 & 1 & 0.6 & 0.5 & 1 & 0.6 \\
\hline \multirow{2}{*}{ RDW (fL) } & $77.4 \pm$ & $125.9 \pm$ & $78.8 \pm$ & $71.7 \pm$ & $108.0 \pm$ & $74.9 \pm$ & $83.2 \pm$ & $113.0 \pm$ & $74.8 \pm$ \\
& 0.7 & 0.6 & 0.6 & 0.7 & 0.6 & 0.6 & 0.7 & 0.6 & 0.6 \\
\hline PLT (109/L) & $523 \pm 3$ & $184 \pm 3$ & $682 \pm 5$ & $345 \pm 3$ & $705 \pm 6$ & $633 \pm 5$ & $539 \pm 3$ & $485 \pm 5$ & $624 \pm 5$ \\
\hline \multirow{2}{*}{ MPV (fL) } & $15.9 \pm$ & $16.3 \pm$ & $14.5 \pm$ & $15.2 \pm$ & $14.0 \pm$ & $13.9 \pm$ & $14.8 \pm$ & $14.8 \pm$ & $14.0 \pm$ \\
& 0.1 & 0.2 & 0.1 & 0.2 & 0.2 & 0.1 & 0.2 & 0.2 & 0.1 \\
\hline \multirow{2}{*}{ PDW (fL) } & $21.7 \pm$ & $16.2 \pm$ & $18.2 \pm$ & $23.3 \pm$ & $14.8 \pm$ & $16.0 \pm$ & $16.6 \pm$ & $15.2 \pm$ & $16.4 \pm$ \\
& 0.3 & 0.3 & 0.2 & 0.3 & 0.3 & 0.2 & 0.3 & 0.3 & 0.2 \\
\hline \multirow{2}{*}{ P-LCR } & $0.353 \pm$ & $0.343 \pm$ & $0.217 \pm$ & $0.346 \pm$ & $0.166 \pm$ & $0.155 \pm$ & $0.264 \pm$ & $0.242 \pm$ & $0.158 \pm$ \\
& 0.003 & 0.005 & 0.005 & 0.002 & 0.007 & 0.005 & 0.003 & 0.002 & 0.005 \\
\hline \multirow{2}{*}{ WBC (109/L) } & $11.3 \pm$ & $5.3 \pm$ & $9.9 \pm$ & $9.6 \pm$ & $9.0 \pm$ & $9.7 \pm$ & $11.2 \pm$ & $8.5 \pm$ & $9.8 \pm$ \\
& 0.3 & 0.3 & 0.3 & 0.3 & 0.3 & 0.3 & 0.3 & 0.3 & 0.3 \\
\hline LYM (109/L) & $6.4 \pm 0.1$ & $4.4 \pm 0.1$ & $6.0 \pm 0.1$ & $5.4 \pm 0.1$ & $7.3 \pm 0.1$ & $4.7 \pm 0.1$ & $6.7 \pm 0.1$ & $7.2 \pm 0.1$ & $5.7 \pm 0.1$ \\
\hline \multirow{2}{*}{ SI ( $\mu$ mol/L) } & n.d. & n.d. & $10.87 \pm$ & n.d. & n.d. & $18.37 \pm$ & n.d. & n.d. & $41.1 \pm$ \\
\hline & & & 0.87 & & & 1.63 & & & 1.1 \\
\hline
\end{tabular}

RBC decreased significantly more than 2 times, after inducing anemia in all experimental groups. The control group (Ia), considered as the reference one, revealed the normal levels of RBC, which reverted due to special diet administration.
As for the IIa and IIIa groups fed with fortified bread (FB), an improvement of this index compared to the initial parameters before the anemia was induced when the RBC increased with 5\% and $10 \%$ respectively. 
After PHZ-induced anemia, the HGB decreased almost twice in all 3 investigated groups. Special food administrated to the animals from the Ia group leaded to rehabilitation of the HGB amount up to normal levels. In the case of the animals fed with FB (IIa and IIIa) an increase of the HGB was noticed, the values were more than $7 \%$ higher compared to the indexes before anemia. This fact proved the curative effect of the iron FB, due to its significant bioavailability.

Table 2. Leukocyte formula for the laboratory animals before PHZ-induced anemia (BA), after PHZinduced anemia (AA) and after special dietary administration (ASD).

\begin{tabular}{|c|c|c|c|c|c|c|c|c|c|}
\hline \multirow{2}{*}{$\begin{array}{c}\text { Blood } \\
\text { parameters }\end{array}$} & \multicolumn{3}{|c|}{ Ia } & \multicolumn{3}{|c|}{ IIa } & \multicolumn{3}{|c|}{ IIIa } \\
\hline & BA & AA & ASD & BA & AA & ASD & BA & $\mathrm{AA}$ & ASD \\
\hline $\begin{array}{l}\text { MC and mMC } \\
(\%)\end{array}$ & 0 & 0 & $\begin{array}{l}1.8 \pm \\
0.57\end{array}$ & 0 & $\begin{array}{c}1.2 \pm \\
0.9\end{array}$ & $\begin{array}{l}3.4 \pm \\
0.49\end{array}$ & 0 & 0 & $\begin{array}{l}4.5 \pm \\
0.51\end{array}$ \\
\hline $\begin{array}{l}\text { Unsegmented } \\
\text { neutrophils } \\
(\%)\end{array}$ & $\begin{array}{l}1.7 \pm \\
0.20\end{array}$ & $\begin{array}{l}0.4 \pm \\
0.20\end{array}$ & $\begin{array}{l}0.8 \pm \\
0.20\end{array}$ & $\begin{array}{l}1.0 \pm \\
0.70\end{array}$ & $\begin{array}{l}0.8 \pm \\
0.20\end{array}$ & $\begin{array}{l}1.0 \pm \\
0.20\end{array}$ & $\begin{array}{l}0.7 \pm \\
0.30\end{array}$ & $\begin{array}{l}0.4 \pm \\
0.20\end{array}$ & $\begin{array}{c}1.0 \pm \\
0.3\end{array}$ \\
\hline $\begin{array}{l}\text { Segmented } \\
\text { neutrophils } \\
(\%)\end{array}$ & $\begin{array}{c}29.0 \\
\pm \\
2.0\end{array}$ & $\begin{array}{c}40.0 \pm \\
7.0\end{array}$ & $\begin{array}{c}34.0 \pm \\
2.0\end{array}$ & $\begin{array}{c}28.0 \pm \\
2.0\end{array}$ & $\begin{array}{c}32.0 \pm \\
7.0\end{array}$ & $\begin{array}{c}31.0 \pm \\
3.0\end{array}$ & $\begin{array}{c}31.0 \pm \\
3.0\end{array}$ & $\begin{array}{c}30.0 \pm \\
2.0\end{array}$ & $\begin{array}{c}26 \pm \\
2.0\end{array}$ \\
\hline $\begin{array}{l}\text { Eosinophils } \\
(\%)\end{array}$ & $\begin{array}{c}0.7 \pm \\
0.3\end{array}$ & $\begin{array}{c}0.4 \pm \\
0.2\end{array}$ & $\begin{array}{c}0.6 \pm \\
0.3\end{array}$ & $\begin{array}{c}0.8 \pm \\
0.5\end{array}$ & $\begin{array}{l}1.2 \pm \\
0.6\end{array}$ & $\begin{array}{c}0.8 \pm \\
0.3\end{array}$ & $\begin{array}{c}0.8 \pm \\
0.5\end{array}$ & $\begin{array}{c}0.4 \pm \\
0.2\end{array}$ & $\begin{array}{c}0.8 \pm \\
0.3\end{array}$ \\
\hline Basophils (\%) & $\begin{array}{c}1.0 \pm \\
0.4\end{array}$ & $\begin{array}{c}0.4 \pm \\
0.2\end{array}$ & $\begin{array}{c}0.8 \pm \\
0.2\end{array}$ & $\begin{array}{c}1.2 \pm \\
0.9\end{array}$ & $\begin{array}{c}0.8 \pm \\
0.2\end{array}$ & $\begin{array}{c}1.0 \pm \\
0.7\end{array}$ & $\begin{array}{c}1.0 \pm \\
0.4\end{array}$ & $\begin{array}{c}0.2 \pm \\
0.4\end{array}$ & $\begin{array}{c}1.0 \pm \\
0.3\end{array}$ \\
\hline LYM (\%) & $\begin{array}{c}60.0 \pm \\
2.0\end{array}$ & $\begin{array}{c}51.0 \pm \\
6.0\end{array}$ & $\begin{array}{c}52.0 \pm \\
1.7\end{array}$ & $\begin{array}{c}62.0 \pm \\
1.0\end{array}$ & $\begin{array}{c}56.0 \pm \\
5.0\end{array}$ & $\begin{array}{c}52.0 \pm \\
2.5\end{array}$ & $\begin{array}{c}59.0 \pm \\
3.0\end{array}$ & $\begin{array}{c}61.0 \pm \\
3.0\end{array}$ & $\begin{array}{c}55.0 \pm \\
1.4\end{array}$ \\
\hline MONO (\%) & $\begin{array}{c}7.6 \pm \\
1.1\end{array}$ & $\begin{array}{c}7.6 \pm \\
1.1\end{array}$ & $\begin{array}{c}10.0 \pm \\
2.0\end{array}$ & $\begin{array}{c}7.0 \pm \\
1.2\end{array}$ & $\begin{array}{c}8.6 \pm \\
1.7\end{array}$ & $\begin{array}{c}10.0 \pm \\
1.8\end{array}$ & $\begin{array}{c}7.0 \pm \\
0.8\end{array}$ & $\begin{array}{c}8.0 \pm \\
0.5\end{array}$ & $\begin{array}{c}11.8 \pm \\
1.8\end{array}$ \\
\hline Normocyte & - & ++++ & - & - & ++ & - & - & - & - \\
\hline
\end{tabular}

The HCT decreased significantly after PHZ-induced anemia with approximately $25-44 \%$, then rehabilitated reaching the initial level in the control group and even insignificantly exceeded the initial value for the animal groups fed with FB.

The MCV significantly increased after the PHZ-induced anemia with up to $60-79 \%$, which indicated the presence of a severe anemia and can be considered as an accommodation and compensation reaction. The aforementioned parameter reverted to its normal values after 3 weeks of fortified food administration (groups IIa and IIIa). The value of the final parameter reached the initial level in the control group.

The MCHC has been reduced with about 120-150 units (with 18-21\%) after the PHZ-induced anemia, which did not revert to the initial value in control group. For the IIa and IIIa groups of animals, which were fed with FB, there was slight increase tendency for the MCHC compared to the initial values.

The RDW increased considerably (with 40-50 units, 35-63\%) after the PHZ-induced anemia, then reverted to the normal values for the control group as well as for the groups fed with FB.

PLT varied considerably after the PHZ-induced anemia was reestablished due to a special diet administration for the control group, as well as for the animal groups fed with FB.

The MPV did not change significantly after the PHZ-induced anemia, however, after the special diet, the above mentioned parameter had a slight decrease tendency, which maintained at almost the same values for all the groups studied.

The PDW did not decrease essentially after the anemia was induced and reverted to the initial value after the special diet administration for the control group as well as for the iron FB fed groups.

The P-LCR decreased significantly, especially for the groups IIa and IIIa, where this parameter due to a special diet administration maintained at low values.

Once anemia was induced by phenylhydrazine the WBC decreased, especially for the control group - Ia (tab. 1). After the special diet administration during 3 weeks, the WBC reverted to the normal values for all groups (Ia - IIIa). 
The LYM varied considerably after the PHZ-induced anemia and remained at low levels, being inferior to the ones registered before the anemia was induced in all the groups studied.

The table 1 shows the evolution of serum iron (SI) after application of special diet in the presence of PHZ-induced anemia. It was established that in the experimental groups with PHZ-induced anemia after the special diet administration the level of the SI increased from $10.87 \pm 3.67 \mu \mathrm{mol} / \mathrm{L}$ for group Ia to $41.10 \pm 17.23 \mu \mathrm{mol} / \mathrm{L}$ for group IIIa, where animals were fed with fortified bread with iron prepared by lactic-acid method (20).

Our data revealed that after PHZ-induced anemia, unsegmented neutrophils slightly decreased in the peripheral blood, while segmented tended to increase, as well as normocytes were formed (tab. 2).

After induction of anemia, the LYM\% in the leukocyte formula did not undergo any relevant changes for all three groups of investigated animals. This parameter decreased slightly compared to the normal values in all studied groups after the administration of the special diet rich in iron. The decrease was followed by elevated percentage of monocytes and granulocytes in all studied groups, which slightly exceeded the initial values after the administration of the special diet.

Therefore, these modifications were more obvious for the animals fed with fortified bread prepared by lactic-acid fermentation.

\section{DISCUSSIONS}

The circulating red blood cells (erythrocytes), their precursors, and all body elements involved in the production of red blood cells make up the concept of erythron (23), and the state of the erythron can be determined by the number of red blood cells (RBC), HBG concentration, HCT level (volume of packed cells) and also on the basis of erythrocyte indices - MCV, MCHC, RDW.

The present study showed that the average level of erythron indices decreased after PHZ-induced anemia in all experimental groups and within the same limits as the average content of HGB in red blood cells - by $25-30 \%$.

The results showed that erythrocyte indices (especially the MCHC index, which reflects the degree of erythrocyte saturation with hemoglobin) returned to the initial level after ASD, especially in group IIIa, where the animals were fed with iron-fortified bread obtained by lactic acid fermentation.

A decrease in MCHC (hypochromia) was caused by iron deficiency and a decrease in HBG synthesis occurred after modeling of PHZ-induced anemia. Thus, the administration of iron-fortified bread prepared by the method of lactic fermentation significantly improved the impaired erythron state caused by PHZ-induced anemia.

These data correspond to the results (24), which showed that foods fermented with lactic acid increase the absorption of $\mathrm{Fe}$ in human subjects, possibly by lowering the $\mathrm{pH}$, activating phytases and forming soluble Fe complexes and organic acids.

SI concentration is an indicator of the iron quantity present in the plasma, fixed by a specific protein - transferrin. Based on the obtained data regarding iron absorption process, transport, hoarding, usage and elimination, the plasma iron balance could be established, as well as body iron requirements in different physiological environments.

In different disorders, the SI assessment indicates a decrease of the serum iron towards severe iron deficiency and an increase of this parameter for iron overdose, as well as megaloblastic anemia, hemolytic anemia and sideroblastic anemia. Commonly the iron transport parameters do not change, until body iron reserves are completely exhausted. The SI is the main indicator of iron therapy response during the convalescence period, following a severe anemia.

Regulation of the iron absorption is possible due to the intervention of two proteins from the intestinal mucous membrane (especially from duodenum), namely ferritin and a protein similar with serum transferrin named mucous transferrin (25). In iron deficiency, the concentration and synthesis speed increases in the mucous and the synthesis of the apoferritin from the duodenal cells decreases, this means that the absorbed iron will not be fixed in the cells as ferritin but will be transferred towards the plasma. On the other hand, in iron overcharge, the transferrin synthesis in mucous is reduced, however, the apoferritin production increases, which fixes the iron in the cells as in a non-absorbable form, being then released from the body through feces, when the cells that fixed them exfoliate. 
Systemic iron homeostasis is regulated by the interaction of the peptide hormone, hepcidin and the iron exporter, ferroportin $(26,27)$, which coordinate the iron acquisition and use. Hepcidin levels are increased during iron sufficiency and inflammation and are decreased in hypoxia or erythropoiesis. Hepcidin is a negative regulator of iron export. Hepcidin binds to cell surface ferroportin, inducing ferroportin, degradation and decreasing cellular iron export.

Recently, the role of other protein structures, especially of the transferrin receptors and the delta aminolevulinic acid from the cells of the erythroid series (eALAS) has been demonstrated, this being the key enzyme in the heme porphyrin component synthesis pathway. It was also observed that protein synthesis and of the abovementioned enzymes are controlled by a "sensor" capable to feel the iron availability of the cells. This sensor is a 28-nucleotide messenger ribonucleic acid (mRNA) fragment. Due to a specific protein binding, the sensor modifies the mRNA translation process for ferritin, transferrin receptors and eALAS, which regulate the protein synthesis within the ribosome.

The abovementioned nucleotide fragment is called the iron responsive element (IRE) and the binding protein is called IRE-BP. It was proved that depending on the iron bioavailability in the cells, IRE-BP modifies its binding affinity towards IRE and affects the translation of the mRNA (28).
When the iron amount in the cells decreases, IREBP increases its affinity towards nucleotide fragment IRE of the messenger nucleic acids, which encodes ferritin and eALAS synthesis, restricts the translation of these messenger nucleic acids and reduces ferritin and eALAS synthesis. At the same time, the IRE-BP complex produces a stabilization of the mRNA, which encodes the receptors for the transferrin, leading to an increase of the synthesis of these receptors.

Conversely, an increase of the iron amount from the cells decreases the IRE-BP affinity towards nucleic fragment IRE from the specific messenger nucleic acids (mRNA) that encode the ferritin and eALAS, thus their translation is performed in optimal conditions and the protein and the aforementioned enzyme synthesis is amplified. Simultaneously, when IRE-BP cannot bind to IRE from the mARN, which encodes the receptors for transferrin, the mARN is less stable and the synthesis of aforementioned receptors decrease.

Thus, the intake of iron fortified bread, prepared by lactic-acid fermentation method leads to normal iron levels and better major blood indexes in phenylhydrazine - induced anemia. The bread enables to fulfill the serum iron reserves for the laboratory animals, since the lactic acid fermentation inhibits the activity of phytates, which are the antinutrients present in flour that commonly make iron unavailable for absorption.

\section{CONCLUSIONS}

1. During a severely induced anemia in laboratory animals, the rehabilitation of blood biochemical indices occurred similarly in rats from all groups, fed with iron-fortified bread, due to an increased iron intake.

2. In case of the group of rats, fed with bread prepared by lactic acid fermentation method, the serum iron amount was rehabilitated completely during the experiment (21 days).

3. For the experimental group, fed with fortified bread that was prepared by traditional method, the serum iron concentration rehabilitated only partially $40-45 \%$, compared to the initial value (before the anemia was induced).

4. The control group rats, fed with non-fortified bread prepared via the traditional method, showed only $1 / 3$ serum iron amount out of the normal range, after the experiment was finished.

5 . The leukocyte count of the blood samples, collected from the animals with and without induced anemia, showed that the intake of iron-fortified bread, prepared via the lactic-acid fermentation method, leads to normal and even improved major blood indices, since it enables to better rehabilitate the serum iron levels within the laboratory animals.

6. The experimental investigations revealed that even in case of a sufficient iron intake, the rehabilitation of the body iron reserve depends considerably on the presence of the anti-nutritive factors (such as phytates in this case). 
7. In order to decrease the impact of these factors, the manufacture of the bread products fortified with micronutrients of mineral origin (iron) could be based on the use of the procedures that involve lacticacid fermentation, developed on wheat bran; development of these procedures can increase micro- and macronutrients bioavailability in the bread.

\section{ACKNOWLEDGMENT}

Authors would like to thank State Project 20.80009.5107.09 - Improvement of food quality and safety by biotechnology and food engineering.

\section{REFERENCES}

1. WHO. The global prevalence of anemia in 2011. Geneva: World Health Organization, 2015.

2. Global nutrition targets 2025: anaemia policy brief. Geneva: World Health Organization; 2014. http://apps.who.int/iris/bitstream/10665/ 148556/1/WHO_NMH_NHD_14.4_eng

3. Kozuki N, Lee AC, Katz J. Child Health Epidemiology Reference Group. Moderate to severe, but not mild, maternal anaemia is associated with increased risk of small-for-gestational-age outcomes. The Journal of Nutrition. 2012; 142: 358-62.

4. Unicef (2002): Food and human nutrition in the Republic of Moldova. UNICEF Report.

5. Hurrell R, Ranum P, de Pee S, Biebinger R, Hulthen L, Johnson Q, Lynch S. Revised recommendations for iron fortification of wheat flour and an evaluation of the expected impact of current national wheat flour fortification programs. Food and Nutrition Bulletin. 2010; 31(1): S7-21.

6. Salgueiro MJ, Zubillaga M, et al. Fortification strategies to combat zinc and iron deficiency. Nutrition Reviews. 2002; 60 (2): 52-58.

7. Steven A. New approaches to iron fortification: role of bioavailability studies. The American Journal of Clinical Nutrition. 2004; 80: 1104-1105.

8. Nestel P, Nalubola RN. Wheat flour fortification with iron. Arlington, VA, The MOST Project, 2000 http:/www.mostproject.org.pubs.htm [Accessed 10th April 2020].

9. Bryszewska MA, Laghi L, et al. Bioavailability of Microencapsulated Iron from Fortified Bread Assessed Using Piglet Model. Nutrients. 2017; 9(3): 272.

10. Tseng $M$, Chakraborty $H$, et al. Adjustment for iron intake for dietary enhancers and inhibitors in population studies: bioavailable iron in rural and urban residing Russia women and children. The Journal of Nutrition. 1997; 127: 1456-1468.

11. Hallberg L, Hulthen L, Gramatkovski E. Iron absorption from the whole diet in men: How effective is the regulation of iron absorption? The American Journal of Clinical Nutrition. 1997; 66: 347-356.

12. Torre M, Rodriguez AR. Effects of dietary fiber and phytic acid on mineral availability. Critical Reviews in Food Science and Nutrition. 1991; 1: 1-22.

13. Turk M., Carlsson NG, Sandberg AS. Reduction in the levels of phytate during wholemeal bread making: effect of yeast and wheat phytases. Journal of Cereal Science. 1996, 23:257-264.

14. Rodriguez-Ramiro I, Brearley CA, et al. Assessment of iron bioavailability from different bread making processes using an in vitro intestinal cell model. Food Chemistry. 2017; 228:91-98.

15. Aslam MF, Ellis PR, et al. Enhancing mineral bioavailability from cereals: Current strategies and future perspectives. Nutrition Bulletin. 2018; 43(2): 184-188.

16. Walter Lopez H, Duclos V, et al. Making bread with sourdough improves mineral biovailability from reconstituted whole wheat flour in rats. Nutrition. 2003; 19: 524-530.

17. Walter Lopez H, Krespine V, et al. Prolonged fermentation of whole wheat sourdough reduces phytate level and increases soluble magnesium. Journal of Agricultural and Food Chemistry. 2001; 49: 2657-2662.

18. Diego Quintaes K, Barberá R,Cilla A. Iron bioavailability in iron-fortified cereal foods: The contribution of in vitro studies. Critical Reviews in Food Science and Nutrition. 2017; 57(10):2028-2041.

19. Nikooyeh B, Neyestani TR. Higher bioavailability of iron from whole wheat bread compared with ironfortified white breads in caco-2 cell model: an experimental study. Journal of the Science of Food and Agriculture. 2007; 97(8): 2541-2546.

20. Sturza R, Gudumac V, Deseatnicov O, Ciobanu C. The influence of the bread making procedure on the iron bioavailability. Scientific Study \& Research. 2009; 10(1), 53-66.

21. G. D. of R. M. No. 68 from January 29, 2009 regarding the approval of Technical Regulation on Flour, wheat and bran. Official Monitor of the Republic of Moldova, 06.02.2009, no. 23-26, art. 107 (in Romanian).

22. Hoff J. Methods of blood collection in the mouse. Lab animal. 2000; 29(10): 47-53.

23. Miller-Keane Encyclopedia and Dictionary of Medicine, Nursing, and Allied Health, Seventh Edition. 2003 by Saunders, an imprint of Elsevier, Inc.

24. Bering S, Suchdev, et al. A lactic acid-fermented oat gruel increases non-haem iron absorption from a phytate-rich meal in healthy women of childbearing age. Br J Nutr. 2006; 96(1):80-5.

25. Hallberg L. Food iron absorption. In: Cook JD, ed. Methods in hematology. London: Churchill. 1980; 1:116-133.

26. De Domenico I, Ward DM, Kaplan J. Hepcidin and ferroportin: the new players in iron metabolism. Semin Liver Dis. 2011; 31(3):272-9. 
27. Kaplan J, Ward DM, De Domenico I. The molecular basis of iron overload disorders and iron-linked anemias. Int J Hematol. 2011; 93(1):14-20.
28. Yip R. Iron. In: B.A. Bowman, R.M. Russel (Eds), Present Knowledge in Nutrition. Washington, DC: ILSI Press, 2001, 311-322.

Date of receipt of the manuscript: 10/04/2020

Date of acceptance for publication: 25/09/2020

Rodica STURZA, ORCID ID: 0000-0002-2412-5874, SCOPUS Author ID: 55247976800

Valentin GUDUMAC, ORCID ID: 0000-0001-9773-1878, SCOPUS Author ID: 57204126291

Olga DESEATNICOVA, ORCID ID: 0000-0003-4801-8173

Aliona GHENDOV-MOSANU, ORCID ID: 0000-0001-5214-3562, SCOPUS Author ID: 5719927211, Web of Science ID researche R-7240-2018 